\title{
Outbreak reporting guide
}

\section{Correspondence: ccdr-rmtc@phac-aspc.gc.ca}

Outbreak reports describe an outbreak once it is complete. They summarize how the outbreak was detected, the investigations that were conducted, the interventions that were carried out to control it, provide descriptive epidemiology and outcomes. They are useful to identify emerging risks and to describe new investigations or intervention techniques. Outbreak reports are typically 2,000-2,500 words in length - excluding the abstract, tables and references.

The Canada Communicable Disease Report (CCDR) has adapted the Outbreak Reports and Intervention studies Of Nosocomial infection (ORION) reporting guideline (1) for community-based outbreaks.

Table 1 provides an outbreak report checklist and Figure 1 illustrates an example of an epidemic curve, or histogram in which the number of new cases of a disease is plotted against an interval of time to describe a specific outbreak.

As with all submissions, check CCDR's Information for authors (typically published in January every year with the first issue of each new volume) for general manuscript preparation and submission requirements.

\section{Table 1: Checklist of items to include when reporting on an outbreak}

\begin{tabular}{|c|c|c|}
\hline $\begin{array}{l}\text { Reporting } \\
\text { item }\end{array}$ & $\mathbf{N}^{01}$ & Description \\
\hline \multicolumn{3}{|l|}{ Title } \\
\hline Title & 1 & $\begin{array}{l}\text { Compose a title that includes the term "outbreak", the disease, population or place } \\
\text { and time. }\end{array}$ \\
\hline \multicolumn{3}{|l|}{ Abstract } \\
\hline $\begin{array}{l}\text { Structured } \\
\text { summary }\end{array}$ & 2 & $\begin{array}{l}\text { Use a structured format for the abstract with the following section headings: } \\
\text { Background, Objective, Methods, Outcome and Conclusions. }\end{array}$ \\
\hline \multicolumn{3}{|l|}{ Introduction } \\
\hline Setting & 3 & Describe the setting (community, hospital, etc.) where the outbreak occurred. \\
\hline Identification & 4 & Describe the events that led to the discovery of the index case of the outbreak. \\
\hline Background & 5 & $\begin{array}{l}\text { Provide the scientific context (e.g., describe the organism and whether it is } \\
\text { emerging, epidemic, endemic etc.). }\end{array}$ \\
\hline Rationale & 6 & $\begin{array}{l}\text { Identify the clinical and public health rationale to report outbreak (e.g., need for } \\
\text { heightened awareness, demonstration of a new investigation or intervention } \\
\text { technique). }\end{array}$ \\
\hline Objective & 7 & $\begin{array}{l}\text { Articulate the objective of the outbreak report. (e.g., "The objective of this report is to } \\
\text { describe the epidemiological, diagnostic and genetic investigation of the outbreak } \\
\text { that occurred in --). }\end{array}$ \\
\hline \multicolumn{3}{|l|}{ Method } \\
\hline Overview & 8 & $\begin{array}{l}\text { Identify the start and finish dates of the outbreak and the date the investigations } \\
\text { began. Describe how the end date was determined including the incubation period } \\
\text { and date of the last reported case. }\end{array}$ \\
\hline \multirow{2}{*}{$\begin{array}{l}\text { Case finding } \\
\text { and data } \\
\text { collection }\end{array}$} & 9 & $\begin{array}{l}\text { Provide the case definitions (including confirmed, probable and under investigation if } \\
\text { applicable). }\end{array}$ \\
\hline & 10 & $\begin{array}{l}\text { Describe data collection activities (for person, time and place) including any } \\
\text { questionnaire development (clinical history, risk factor assessment). }\end{array}$ \\
\hline
\end{tabular}




\begin{tabular}{|c|c|c|}
\hline Investigations & 11 & $\begin{array}{l}\text { Provide a systematic description of how the outbreak was investigated including } \\
\text { - } \quad \text { Laboratory investigations, and } \\
-\quad \text { Environmental sampling. }\end{array}$ \\
\hline \multirow{3}{*}{$\begin{array}{l}\text { Epidemiologic } \\
\text { and statistical } \\
\text { analyses }\end{array}$} & 12 & $\begin{array}{l}\text { Describe any analytical methods used assess the outbreak (e.g., risk factor } \\
\text { analysis, survival analysis, estimation of background rates). }\end{array}$ \\
\hline & 13 & $\begin{array}{l}\text { Reference any complex analytical methods used (e.g., social network analysis, } \\
\text { estimation of R0). }\end{array}$ \\
\hline & 14 & $\begin{array}{l}\text { Include any sub-group analyses, what was done to control for interactions and } \\
\text { confounding factors and how missing data and reporting delays were addressed. }\end{array}$ \\
\hline Interventions & 15 & $\begin{array}{l}\text { Describe the clinical and public health measures that were put in place to control the } \\
\text { outbreak including as applicable including } \\
\text { - } \quad \text { Exposure history, } \\
\text { - } \quad \text { Health risk assessment, } \\
\text { - } \quad \text { Clinical treatments, and } \\
\text { - } \quad \text { Public health measures (e.g., quarantine, contact tracing, surveillance, } \\
\text { immunization clinics, risk communications etc.). }\end{array}$ \\
\hline \multicolumn{3}{|l|}{ Results } \\
\hline $\begin{array}{l}\text { Descriptive } \\
\text { epidemiology }\end{array}$ & 16 & Provide an overview of what happened by person, time and place. \\
\hline $\begin{array}{l}\text { Ancillary } \\
\text { analyses }\end{array}$ & 17 & $\begin{array}{l}\text { Provide subgroup analyses and describe the assessment of interactions and } \\
\text { confounders as indicated. }\end{array}$ \\
\hline Complications & 18 & Identify any complications, such as hospitalizations and deaths. \\
\hline $\begin{array}{l}\text { Epidemic } \\
\text { curve }\end{array}$ & 19 & $\begin{array}{l}\text { Provide a figure showing the epidemic curve. In the title include the disease, } \\
\text { population/place and time (year). }\end{array}$ \\
\hline $\begin{array}{l}\text { Frequency } \\
\text { table }\end{array}$ & 20 & $\begin{array}{l}\text { Include a table with demographic characteristics (e.g., age and sex) and symptom } \\
\text { frequency, if applicable. }\end{array}$ \\
\hline \multicolumn{3}{|l|}{ Discussion } \\
\hline Key results & 21 & $\begin{array}{l}\text { Summarize key findings that relate to the report objective, highlighting the new or } \\
\text { important aspects of the outbreak and their significance. }\end{array}$ \\
\hline Comparison & 22 & Consider these findings in relation to the current literature. \\
\hline $\begin{array}{l}\text { Strengths and } \\
\text { weaknesses }\end{array}$ & 23 & Identify strengths and weaknesses of the outbreak investigation and response. \\
\hline Conclusion & 24 & Ensure conclusions address objective and follow from the results. \\
\hline
\end{tabular}


Figure 1: Example of an epidemic curve for a measles outbreak (2)

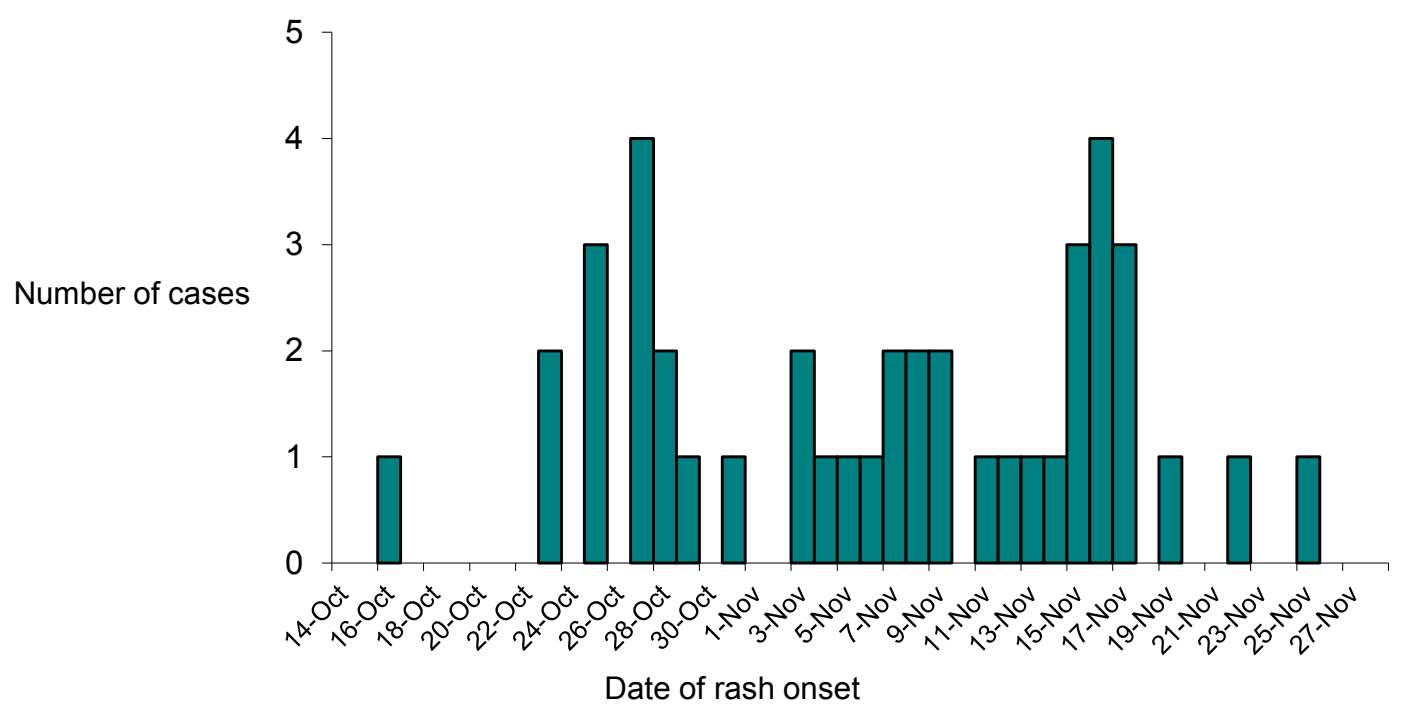

\section{References}

(1) Stone SP, Cooper BS, Kibbler CC, Cookson BD, Roberts JA, Medley GF et al. The ORION statement: Guidelines for transparent reporting of outbreak reports and intervention studies of nosocomial infection. Lancet Infect Dis. 2007;4:282-8.

(2) Kershaw T, Suttorp V, Simmonds K, St. Jean T. Outbreak of measles in a non-immunizing population, Alberta 2013. CCDR. 2014;40:236-242. 